\section{UJMM

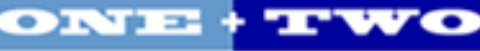

Volume 8 | 2017 Fall 2017

\section{Undergraduate Journal of Mathematical} Modeling: One + Two

2017

\title{
Optimization of a Fuel Cell
}

Eduardo Gines

University of South Florida

Advisors:

Arcadii Grinshpan, Mathematics and Statistics

Scott Campbell, Chemical and Biomedical Engineering

Problem Suggested By: Scott Campbell

Follow this and additional works at: https://digitalcommons.usf.edu/ujmm

Part of the Mathematics Commons

UJMM is an open access journal, free to authors and readers, and relies on your support:

Donate Now

\section{Recommended Citation}

Gines, Eduardo (2017) "Optimization of a Fuel Cell," Undergraduate Journal of Mathematical Modeling: One + Two: Vol. 8: Iss. 1, Article 3.

DOI: http://doi.org/10.5038/2326-3652.8.1.4884

Available at: https://digitalcommons.usf.edu/ujmm/vol8/iss1/3 


\title{
Optimization of a Fuel Cell
}

\begin{abstract}
Fuel cells are devices that generate energy from a chemical reaction that takes place inside the cell. The main parts of these devices are two electrodes and an electrolyte solution. The project consists of determining the area of the electrodes for the fuel cell at which the cell produces its maximum amount of power. This was done with the performance curve of the fuel cell which was in terms of voltage vs current density. The performance curve was turned into terms of power density vs current density, and through this curve the maximum power was determined by identifying the maximum point. The maximum point was determined using the second derivative method. Once the power was obtained, the area of the electrodes could be determined. The performance curves of the voltage and power density of a load with resistance of $5 \Omega$ was plotted with the respective performance curves of the fuel cell in order to determine if the load works with the fuel cell. The project concludes with fuel cell's electrodes having an area of
\end{abstract} $4.218 \mathrm{~cm}^{2}$ which generates a maximum power of $0.058 \mathrm{~W}$ and the load working perfectly at the cell's maximum power.

\section{Keywords}

Fuel Cells, Optimization, Performance Curves

\section{Creative Commons License}

\section{(c) (1)(9)}

This work is licensed under a Creative Commons Attribution-Noncommercial-Share Alike 4.0 License. 


\section{PROBLEM STATEMENT}

A particular hydrogen (5\% in air) fuel cell has the following performance curve: $V=1.10-53 i+2400 i^{2}-46440 i^{3}$, where $V$ is the voltage produced by the cell and $i=I / A$ is the current density where $A$ is the area (in $\mathrm{cm}^{2}$ ) of the cell electrodes and $I$ is the current produced by the cell (in Amps). We will make a plot of $V$ versus $i$ to know the possible ranges of current density and voltage for the cell and also make a plot of power density $P / A$ versus $i$, where $P / A=i V$. The fuel cell is to power a load of resistance $5 \Omega$. Our objective is to determine the electrode area $A$ (in $\mathrm{cm}^{2}$ ) so that the cell is operating at its maximum power point. We are also aiming to find the corresponding power $P$ produced (in W) as well as the current and cell voltage.

\section{MOTIVATION}

A fuel cell is a device that uses a fuel, usually hydrogen, to generate electricity through a chemical reaction. The fuel consists of two electrodes: a positive called cathode and a negative called anode, and an electrolyte that transports the electrical charged particles between the electrodes (Wallace). In summary, the process of the fuel cell is the combustion of hydrogen gas to form water. The hydrogen molecules are oxidized in the anode forming electron (e-) and ionized hydrogen molecules $(\mathrm{H}+)$. The formed electron passes through a metal to cathode. This movement of the electrons from the anode to the cathode is what generates the electric current. Later in the cathode, the hydrogen ions and the electrons combine with oxygen molecules to form water molecules (Franceschetti).

The importance of the fuel cells is that they do not produce contamination as the other combustion based engines like those of oil or coal. Fuel cells produce water as waste instead of carbon dioxide. Because of the greenhouse effect reducing the emission of carbon dioxide is currently a matter of immense importance. The greenhouse effect is a natural process that warms the surface of the earth. When the solar energy enters the earth, some of it is absorbed by the 
surface while the rest bounces back to space, but some of this remaining energy stays trapped in the surface because of a layer of greenhouse gases in the atmosphere. This greenhouse gases are water vapor, carbon dioxide, methane, nitrous oxide, ozone and some artificial chemicals. The increase of carbon dioxide emissions in the last decades has increased the amount of greenhouse gases in the atmosphere which leads to more heating the earth more than it is supposed to (Australian Department of Environment and Energy). According to NASA, most scientists agree that the greenhouse effect is one of the main causes of global warming. Hence reduction of carbon dioxide emissions is one of the most important ways to fight global warming.

The objective of this project is to optimize a common fuel cell by determining the area of its electrodes at which the cell works at its max potential to power a load with a resistance of 5 $\Omega$. This way proves the potential of fuel cells and promotes their use in order to reduce the amounts of carbon dioxide emitted to the atmosphere.

\section{MATHEMATICAL DESCRIPTION AND SOLUTION APPROACH}

We use the equation for the fuel cell's performance curve:

$$
V=1.10-53 i+2400 i^{2}-46440 i^{3}
$$

Then equation (1) is multiplied by $i$ to get the power density $(P / A)$ performance curve equation since $P / A=i V$. The obtained equation is:

$$
V i=1.10 i-53 i^{2}+2400 i^{3}-46440 i^{4}
$$

Using the second derivative method on equation (2), the max point of the power density performance curve is determined:

$V i=0.0137, \quad i=0.025487, \quad$ Max point is $(0.025487,0.0137)$. 
Using the Power density (Vi) and current density $(i)$ at their max point, the current $(I)$ is determined with their respective equations:

$$
V i=P / A \quad(3) \quad i=I / A \quad(4) \quad I=0.1075 \text {. }
$$

Using the determined current, the area $(A)$ is determined using equation (3). Now that the area is determined, the performance curves for the voltage $\left(V_{\text {load }}\right)$ and the power density $\left(P / A_{\text {load }}\right)$ of the load can be determined. The resulted functions are:

$$
V_{\text {load }}=i A R \quad(5) \quad P / A_{\text {load }}=i^{2} A R \quad(6) \quad A R=21.09 .
$$

Finally, equations (1) and (5) are plotted in one graph to show the performance curve of the voltage $(V)$ of both the load and the cell. Equation (2) and (6) are plotted in one graph also to show the performance curve of the power density $(P / A)$ of both the load and the cell. The intersections points of both graphs are determined.

\section{DISCUSSION}

The results are that the fuel cell operates at its maximum potential when the area of the electrodes is $4.218 \mathrm{~cm}^{2}$ and generates a current of $0.1075 \mathrm{Amp}$, a power of $0.058 \mathrm{~W}$, and a voltage of $0.538 \mathrm{~J} / \mathrm{C}$. The plotted functions of the power density and the voltage of both the fuel cell and load resulted:

\section{Graph 1: Voltage (V) vs current density (i)}




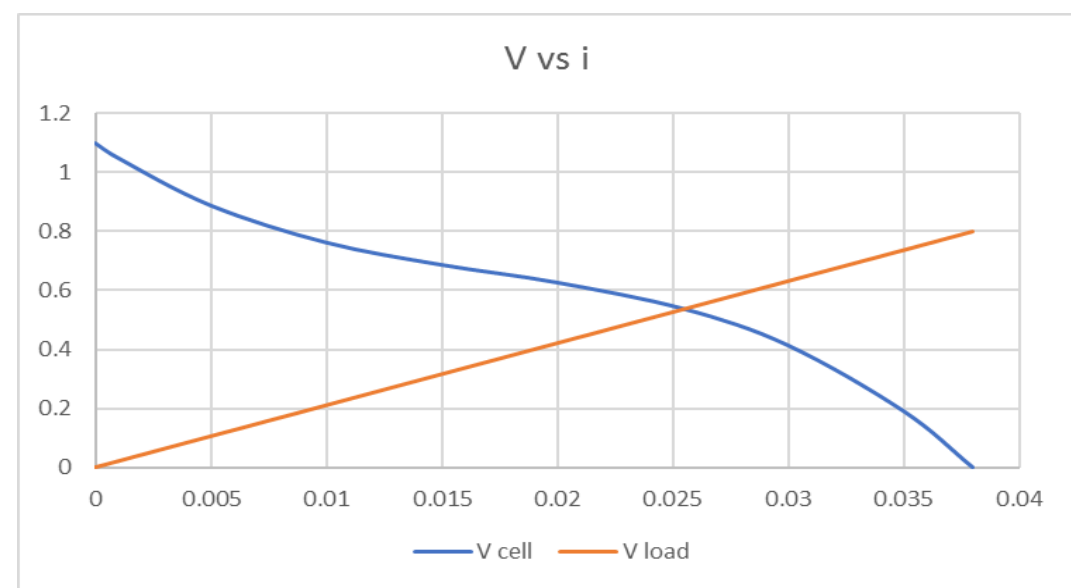

Intersection point $(0.0255,0.5383)$

\section{Graph 2: Power density $(P / A)$ vs current density $(i)$}

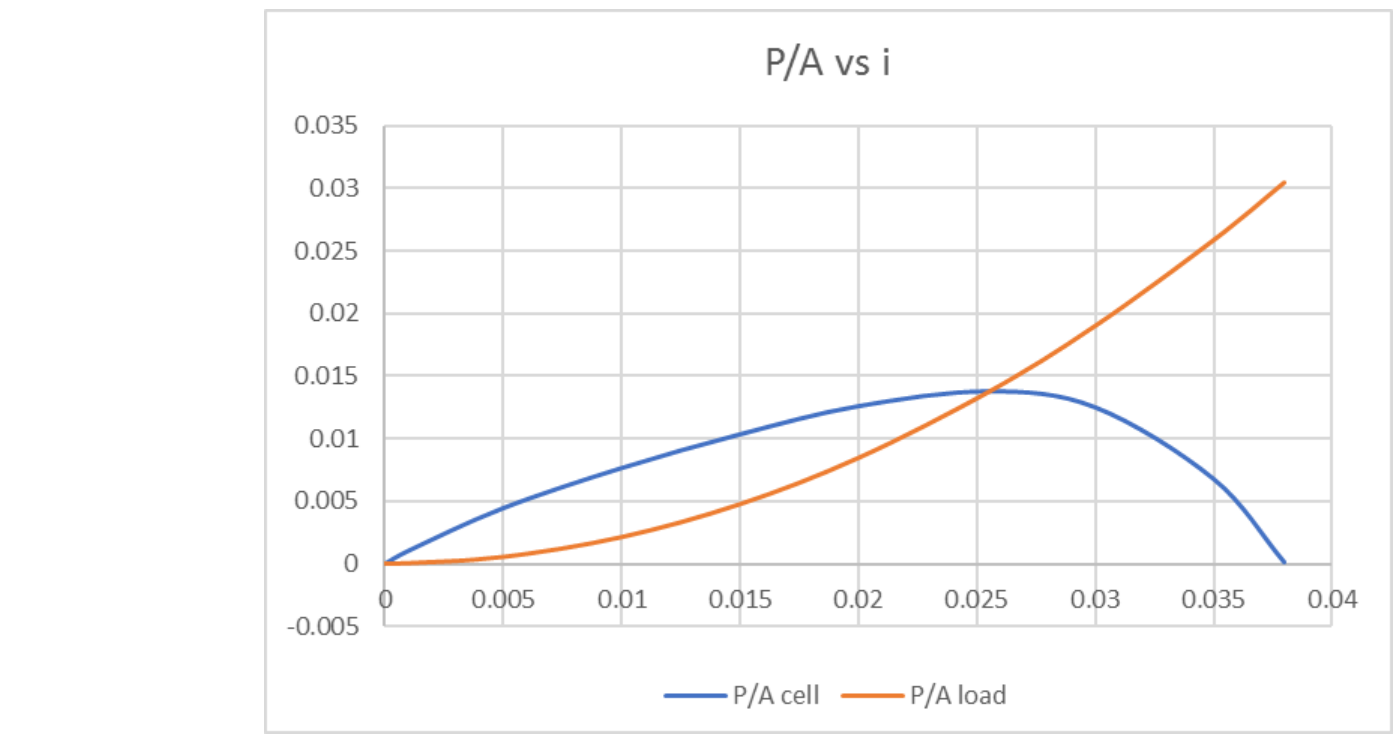

Intersection point $(0.0255,0.0137) \quad$ Max point $(0.0255,0.0137)$

In Graph 1, the functions intercept at the current density (i) value 0.0255 . This intersection shows that the load works with the cell since at that point both the cell and the load have the same current. Graph 2 shows how the power density curve of the load intercepts the power density curve of the fusion cell at its max point. The intersection shows that the load works at the cell's maximum power. The load receives everything the cell generates, energy is not wasted. 
The objective of the project was achieved since the area of the electrodes at which the cell works at its max potential was determined. The result was positive because, theoretically, the load works with this fuel cell at its max potential. The project shows that fuel cell can be efficient and can be used as an alternative to the common combustion engines and this way reduces the production of carbon dioxide and fight against global warming.

\section{CONCLUSION AND RECOMMENDATIONS}

The optimized fuel cell is resulted with electrodes of an area of $4.218 \mathrm{~cm}^{2}$ and generates a current of 0.1075 Amp, a power of $0.058 \mathrm{~W}$, and a voltage of $0.538 \mathrm{~J} / \mathrm{C}$. The load perfectly works with the fuel cell as it can be seen in the graphs. The load works at the cell's max power so there is no energy waste. The project shows that fuel cell can be efficient and can be used as an alternative to the common combustion engines. Substituting combustion engines with fuel cells could reduce the emission levels of carbon dioxide and fight the greenhouse effect and as a result, the global warming.

For the future projects, we recommend including different loads with different areas and/or resistance in order to determine their performance with the fuel cell. Thus different performances of each load with the fuel cell can be seen.

\section{NOMENCLATURE}

\begin{tabular}{|c|c|c|}
\hline$V$ & Voltage & $\mathrm{J} / \mathrm{C}$ \\
\hline$I$ & Current & Amp \\
\hline$P$ & Power & $\mathrm{W}$ \\
\hline$A$ & Area & $\mathrm{cm}^{2}$ \\
\hline
\end{tabular}




\begin{tabular}{|c|c|c|}
\hline$R$ & Resistance & $\Omega$ \\
\hline$i=I / A$ & Current density & $\mathrm{Amp} / \mathrm{cm}^{2}$ \\
\hline$V i=P / A$ & Power Density & $\mathrm{W} / \mathrm{cm}^{2}$ \\
\hline
\end{tabular}

\section{REFERENCES}

Australian Government Department of the Environment and Energy. Greenhouse effect.

http://www.environment.gov.au/climate-change/climate-science/greenhouse-effect.

(Accessed May 3, 2017).

Franceschetti, Donald R. Fuel Cells. Salem Press Encyclopedia of Science, January.

EBSCOhost,

ezproxy.lib.usf.edu/login?url=http://search.ebscohost.com/login.aspx?direct=true $\& d b=e r$ s\&AN=89317015\&site=eds-live. (Accessed May 3, 2017).

NASA. A blanket around the Earth. https://climate.nasa.gov/causes/. (Accessed May 3, 2017).

Wallace, Harold D. Collecting History of Fuel Cells. Smithsonian Institution, 1999. http://americanhistory.si.edu/fuelcells/basics.htm\#top. (Accessed May 3, 2017). 